\title{
Review
}

\section{The structure of world history: From modes of production to modes of exchange}

\author{
Kojin Karatani, translated by Michael K. Bourdaghs, \\ Duke University Press, Durham, NC, 2012, 376pp., ISBN: 978-0822356769
}

Contemporary Political Theory (2017) 16, 290-292. doi:10.1057/cpt.2016.19; advance online publication 14 June 2016

We are living in an age of Big Ideas. Not so long ago, a book like The Structure of World History would have seemed impossible. Every word in its title - even, perhaps, the article and the preposition - would have aroused instant suspicion. Grand narrative of modernity, we would have said. Necessarily exclusionary in its effort to capture everything. Insensitive to difference. Totalizing. Potentially totalitarian. Now, things appear very different. Universalism is back - although, this time, it has a slightly different valence, and a slightly different relationship with that other concept that was until recently more or less forbidden, namely truth.

In the English-speaking world, Kojin Karatani appeared on the scene in 2003 with the translation of his Transcritique: On Kant and Marx - a work in which he argued that a number of the apparent contradictions in Marx's thought (particularly between a deterministic account of history and an activist account of politics) must be conceived of as 'antinomies' in the Kantian sense, and that they can be understood alongside one another, not dialectically or oriented towards an eventual synthesis, but via what Karatani called a 'parallax view' (this being where Žižek derived the title of his book of the same name). If Transcritique was a decidedly philosophical work, The Structure of World History, as the title indicates, is decidedly historical. More accurately, here Karatani seeks to contribute to a Marxist tradition of anthropological historiography, and especially to what Wallerstein calls 'world systems theory'.

While, as I will try to suggest in a moment, the details get rather sophisticated and surprising, the overall argument of The Structure of World History can be stated quite directly. To understand human history, Karatani suggests, we must think, not in terms of what Marx called 'modes of production', but in terms of what he calls 'modes of exchange'. Here the word 'exchange' has an expansive meaning, including everything from economic exchange to symbolic exchange in the widest possible sense. Once we make this shift, Karatani proposes, we are no longer stuck with Marx's base/superstructure model. Now things like politics and culture are no longer seen as instruments or epiphenomena of economics. Rather, we can think all

(c) 2016 Macmillan Publishers Ltd. 1470-8914 Contemporary Political Theory Vol. 16, 2, 290-292 www.palgrave.com/journals 
three - culture, politics and economics - as co-determined. For Karatani, this is not only a better way of approaching the past; it is also the only way we will begin to understand our current situation, which Karatani characterizes in terms of what he calls the 'Boromean Knot' of 'the Capital-Nation-State trinity' (p. 1).

This notion of the mode of exchange, and of the co-determination of culture, politics and economics, is then brought to bear on the study of history, which Karatani represents in terms of four basic modes of exchange - what he calls modes A, B, C and D. It is important to note that, for Karatani, these are historical structures, not historical periods or stages. That is to say, each mode is always present in some manner; but at the same time, one is always the 'structure in dominance' (to borrow a phrase from Althusser, whom Karatani appears to be silently following here in more ways than one).

Roughly, then, Mode A involves gift exchange and reciprocity. It is appropriate to nomadic and clan societies. Mode B entails conquest, plunder and redistribution. It emerges alongside formal law, empire and the state. Mode $\mathrm{C}$ consists of commodity exchange and capital. Crucially, for Karatani's argument, it takes shape in what he calls the 'submargin' of the great ancient empires - that is to say, Europe. In other words, for Karatani, capitalism does not appear in Europe because Europe is the most civilized or advanced place on earth. On the contrary, capitalism and commodity exchange, or Mode C, could take shape in Europe precisely because Europe was an irrelevant backwater, so far removed from the empires in which Mode B, or plunder and redistribution, reigned supreme.

The final mode of exchange is Mode D, which Karatani describes as a kind of return of Mode A and the gift, or a 'return of the repressed', but 'in a higher dimension' (p. 8). While Mode D has never been the structure in dominance, at least not on a world historical scale, it has always been present, Karatani maintains, particularly within radical religious movements. Among Marxists, this will perhaps be Karatani's most controversial claim. But he is quite explicitly seeking to return to socialism what he calls its 'religious hue' (p. 8).

After a few of decades of a historicism that emphasized the local, the discrete, the situated and the specific, the fact that Karatani is willing to make sweeping claims about human history, and even explicitly teleological ones, is more than a little refreshing. At the same time, perhaps the most interesting elements of The Structure of World History are to be found in the details. We have already mentioned his striking and unorthodox description of the emergence of capitalism in Europe. He has a similarly unorthodox approach to the emergence of the state. For Karatani, it is not the case that humans discover the agricultural mode of production, settle in one spot rather than wandering nomadically, and then begin to develop a fixed legal and political order. Rather, on Karatani's account, the state takes shape when one warring nomadic clan conquers another, and then sets up an apparatus or administration for both collecting tribute, and, to prevent future struggle, redistributing some of the wealth to a class of local collaborators, or what would eventually transform into a 
bureaucracy. This means, in a sense, that the state has always been something like a welfare state - that it has always been designed to both gather and redistribute wealth. And, for the same reason, cutting the 'Boromean Knot' of 'Capital-NationState' can only mean breaking entirely with the state form.

This is not the place to begin a full-fledged critique of Karatani's project. But I will note, in conclusion, that there is a clear anarchist bent here - one that ultimately must invoke something like the spontaneous self-administration of the social. Perhaps at this point a reference to Agamben's recent work is in order. For in The Kingdom and the Glory, for example, Agamben proposes that any such notion entails something like an 'economic theology' - a thinly veiled reinvention of the theological concept of Providence. Whether he knows it or not, this may help explain why Karatani wants to remind us of socialism's 'religious hue'. It may also give us reason to be a little suspicious of that reminder.

Charles Barbour

Western Sydney University, Penrith, NSW 2751, Australia c.barbour@westernsydney.edu.au 